\title{
George III, Lord North and the defeat of 'faction' (1770)
}

The political contest at the beginning of 1770 marked the culmination of the events of the first decade of George III's reign. The King's opponents pitted the power of the House of Commons against that of the Crown, but circumstances tipped the balance in favour of the monarchy. The success of Lord North enabled George III to defy 'faction' and make good his royal claim to have a Prime Minister of his own choice.

When Parliament met on 9 January neither the eve-of-session meetings nor the debates on the Address presaged a change of administration. If 80 opposition MPs mustered at the Thatched House, 179 met at the ministerial Cockpit. ${ }^{1}$ In the Commons Grenville's constitutional scruples prevented him from trying to amend the Address, but Dowdeswell did so after Chatham had sent Temple to express his concern that otherwise no debate would develop. ${ }^{2}$ The amendment asked the House to take into consideration 'the cause of the unhappy discontent which prevailed in every part of his Majesty's dominions'. The ensuing debate, as befitted this wording, ranged widely over Ireland, America, Corsica, the Civil List, as well, of course, as the Middlesex Election. Attorney-General De Grey and Bedfordite Rigby both pointed out that only a minority of counties and a few boroughs had petitioned. Grenville responded with the claim of 60,000 signatures. Ominous for the ministry was the behaviour of Chathamites still in office. Granby recanted his voting on the Middlesex Election, and Solicitor-General Dunning spoke for the amendment, but Hawke's son supported the ministry. Thomas Townshend, however, though voting in opposition, said that he had refused to sign a petition because of the adverse reflection on that House. That reaction to popular pressure, anticipated by Chesterfield in the summer, and a 
widespread feeling that the amendment was too sweeping a condemnation, contributed to a ministerial triumph by 254 votes to 138 when the debate ended after midnight. ${ }^{3}$

In the Lords Chatham moved a similar amendment, with more emphasis on the Middlesex Election. Camden, though Lord Chancellor, spoke strongly for it, making certain his dismissal, for the King sharply commented that 'the Great Seal never was before in opposition'. ${ }^{4}$ So did Temple, Lyttelton, and Shelburne, but the Rockinghamite peers remained silent, presumably reflecting jealous disapproval of Chatham's lead. Lord Mansfield declared the Commons decision to be no business of the Lords. The ministry had the better of the debate, in the opinion of Horace Walpole, with Chatham being savaged for lack of precision and logic by courtier Denbigh and by Sandwich, and won the division by 89 votes to 36 , eleven proxies being then added to the majority. 'Vociferous has shot his bolt', wrote John Robinson, soon to become Treasury Secretary, 'and will probably come no more this session'. ${ }^{6}$ The King prematurely congratulated Grafton on his Parliamentary success, and complimented him on being 'one man of my own age on whose resolution, abilities, and attachment I can rely on'. ${ }^{7}$ For a few days this government optimism appeared to be justified. Apart from Camden, Granby and Dunning, the Chathamite haemorrhage seemed small, and by no means fatal: one Irish Vice-Treasurer, three Lords of the Bedchamber, and two Lords of the Admiralty, but not Sir Edward Hawke. The ministry, too, was afforded a lull in the Parliamentary battle. The lack of a Lord Chancellor provided a reason to adjourn the Lords until 22 January, and the House of Commons also did no important business before that date because of the illness and resignation of Speaker Sir John Cust.

Grafton sought to take advantage of this respite by patching up the ministry, and offered Charles Yorke the Lord Chancellorship on 13 January. He declined after consulting his family and Rockingham; ${ }^{8}$ but was then bullied into changing his mind by George III on 17 January, with the threat that he would never again have the opportunity. Yorke's already poor health collapsed under the nervous strain, and he died of an internal disorder on 19 January, not by suicide as was widely rumoured at the time. Since Grafton shared that belief, the shock shattered his morale, and he now contemplated resignation. ${ }^{9}$ George III persuaded him instead to postpone that problem by putting the Lord Chancellorship into commission, and Lord Mansfield agreed to act as Speaker in the Lords. Bedford, Gower and Weymouth pressed Grafton to continue, and so did Conway, who also suggested 
an approach to the Rockinghamite party. George III, believing that that would mean a dissolution of Parliament as demanded in some petitions, refused to entertain the idea. A month earlier the King had taken out insurance against Grafton's resignation by an invitation to Lord North on 20 December to take the Treasury in the event of a vacancy. ${ }^{10}$ The Chancellor of the Exchequer was now twice closeted by George III, who also sent Gower and Weymouth on 23 January to press North. The same day the King wrote to North. 'You must easily see that if you do not accept I have no peer at present in my service that I could consent to place in the Duke of Grafton's employment.' ${ }^{11}$

The King was then briefly faced with the prospect of two Premiers instead of none. Before the appointment of North was finalised, Grafton on 25 January told George III that he might continue, for he hoped Attorney-General De Grey would agree to be Lord Chancellor. Grafton's continuance in office was implied by discussion with the King of various other ministerial changes. George III welcomed this news, commenting on 26 January on 'the excellence of your conduct over any of your predecessors since I have mounted the throne. ${ }^{12}$ But that same day Grafton must have finally decided on resignation, after failing to persuade the Attorney-General to become Lord Chancellor. ${ }^{13}$ For, in a letter timed at 9.50 a.m. on 27 January, the King informed Grafton, 'I have seen Lord North, who in the most handsome manner feels he cannot refuse upon this unfortunate occasion coming to my assistance, though not without much reluctance' ${ }^{14}$

These discussions were conducted against a background of Parliamentary debates. On 22 January the Commons elected a Speaker, the ministerial candidate Sir Fletcher Norton being voted into the Chair by 237 votes as against 121 for a last-minute and unwilling opposition nominee Thomas Townshend..$^{15}$ The same day the opposition launched an attack in the Lords, for Chatham persuaded and his own friends shamed the normally mute Rockingham to move for a Committee on the State of the Nation, to examine public grievances. The aim was to provide a forum for Chatham to make a general attack on the ministry. Chatham said himself that he did not know what would take its place, a tacit admission that Rockingham would not cede the Treasury to Grenville. ${ }^{16}$ The Lords fixed 24 January for the Committee, but postponed it then until 2 February because of the illness of both Chatham and Rockingham. ${ }^{17}$ By that date there had been a change of ministry.

In the Commons on 25 January, in a Committee on the State of the Nation, Dowdeswell moved that in election cases the House was bound to judge according to the law of the land, a proposition 
equally impossible for the ministry to reject in principle or to accept in the context of the Middlesex Election. Since the House was in Committee the normal evasive device of the previous question could not be deployed, and great indignation was manifested when ministerialist Lord Clare proposed to end the Committee forthwith. Diarist Henry Cavendish witnessed how the dilemma produced 'some confusion among the gentlemen on the Treasury Bench', for the ministry's procedural expert, Jeremiah Dyson, nursing a grievance over a pension, had refused to attend. After several urgent appeals he sent a form of wording for North to move, to the effect that the resolution of 17 February 1769 declaring that Wilkes having been expelled was 'incapable' of election was 'agreeable to the law of the land'. This device of joining together two propositions was denounced as unfair by opposition speakers, notably Grenville, Wedderburn, Sackville, Burke, and Lord Granby. Administration spokesmen claimed that the right of the House to expel and disqualify MPs was part of the law. When the Commons voted nearly three hours after midnight the amendment was carried by 224 to 180 . Cavendish noted that 'the minority seemed not a little pleased with their numbers in the division, which were greater than they had had upon any other question during the present Parliament'. ${ }^{18}$ Analysis of a minority voting list shows what had happened. Twentysix more MPs had voted in opposition, sixteen of whom had previously voted for administration, a turnaround of forty-two votes in a division. The Chathamite connection directly explained the behaviour of about half this number, and perhaps also of some independent MPs. ${ }^{19}$

There is no direct reference in Grafton's memoirs to the Parliamentary situation, but that it was more than the difficulty of reconstructing the ministry that drove him to resign can be seen from his letter of explanation to the Lord-Lieutenant of Ireland on 30 January. The death of Charles Yorke and the 'inability' to find a Lord Chancellor, he wrote, 'made it unwarrantable for me to stand for the adviser of measures to be discussed only in another place, where I could give no open support'.$^{20}$ The opinion of contemporaries and historians has been that the collapse of the ministerial position in the Commons precipitated his fall, and he knew of that vote before his resignation. What was certainly true was that the sharp drop in the ministerial majority jeopardised Lord North's chance of survival as Prime Minister. Lord Mansfield forecast that the new 'ministry would be beat in the House of Commons two to one'. ${ }^{21}$ 
Grafton's resignation was kept secret for some days, to prevent any mass exodus from the administration, with so many posts still unfilled. North meanwhile busied himself to secure a majority, as when on 29 January he summoned to his house five Court Party MPs, and, as Sir Gilbert Elliot took note, 'stated the resignation, lamented it, mentioned the Duke's reasons, the desire of the King that he (Lord North) should accept as opposition so combined, that no breach could be made there'. Elliot commented that Grafton's resignation 'so unexpected, and so near the last division, ... might possibly cause a great defection'.22

News of Grafton's resignation broke on 30 January. 'The present plan appears to be a trial, with Lord North at the head of the Treasury', was how MP John Calcraft informed his leader Chatham. 'But I have reason to think the court not resolved on this measure, and have some thoughts of sounding your Lordship or other heads of opposition.' The opposition leaders were astonished not to have been summoned, assuming, as Lady Chatham put it, that Grafton's resignation must mean the 'ministry breaking up'. ${ }^{23}$ Courtier Elliot noted the next day. 'Opposition disconcerted with the resignation, mortified that not sent to, their own measures and arrangements not settled, expected and hoped we should propose to adjourn, but it was better determined on our part not to lose a moment but to go on boldly. ${ }^{24}$ North wrong-footed his opponents by the gamble of risking an immediate Parliamentary confrontation in the major Commons debate already scheduled for 31 January. Southern Secretary Weymouth wrote that day that 'the most experienced politicians could not guess' the outcome of recent events. 'It was necessary to wait the fate of two or three questions in the House of Commons before a conjecture could be made about Lord North's situation. ${ }^{25}$

'If the Court should be beaten, the King would be at the mercy of the Opposition.' So did Horace Walpole set the scene for the Commons debate of 31 January 1770, in another meeting of the Committee on the State of the Nation. ${ }^{26}$ The opposition sought North's immediate defeat. Dowdeswell put forward a motion even more difficult to counter than his previous one of 25 January. 'That by the law of the land and the known and established law and custom of Parliament no person eligible of common right to serve in Parliament can be incapacitated by any vote, or resolution of this House, but by Act of Parliament only.' Office-holder Lord Clare at once conceded that 'there is certainly no act of Parliament, upon which Mr Wilkes's incapacity is founded'. That eminent lawyer William Blackstone, shortly 
to leave Parliament for the Bench, argued that the House had acted by exercising judicial rather than legislative power, but ended by admitting that he would have to support Dowdeswell's proposition. Other ministerial lawyers like George Hay and Charles Ambler reiterated the argument that incapacity was the consequence of expulsion, and North took up that point. He also declared the motion to be irregular, since it did not relate to any current business, a reason for him this time to deploy the procedural weapon deemed improper on 25 January, the evasive motion to 'leave the Chair'. Grenvillite Alexander Wedderburn denounced this as a mean device, reminding MPs that it was equivalent to a negative. The debate became heated. Chathamite Barré waxed sarcastic on North's claim that he had taken office out of a sense of duty, not from ambition, jibing that he was not only First Lord of the Treasury and Chancellor of the Exchequer, but also Lord Chancellor, Commander-in-Chief, and two Lords of the Admiralty. Thereby Barré reminded undecided voters of the widespread lack of confidence in North's prospects. The Premier 'replied not only with spirit but good-humour', Walpole recorded, 'and evidently had the advantage, though it was obvious how much weight the personal presence of a First Minister in the House of Commons carried with it'.

The House, diarist Henry Cavendish noted, later became 'so impatient and noisy' that the debate could not continue. North's motion to leave the Chair was carried by a majority of forty, 226 to 186 , greater, Walpole thought, 'by some fifteen or twenty' than the most optimistic ministerial forecast. Opposition journalist John Almon attributed the result to the unfair use of 'Parliamentary craft to prevent the putting a question ... By this means the question was lost, as several of the majority had owned the truth of the proposition, and must have voted for it'. Another reason was that perennial weakness of opposition, failure to muster every supporter: for, although their total had risen only by 6 , they claimed 21 new voters. ${ }^{27}$

The opposition believed the game was still on, but George III thought it virtually over. He commented to North that the majority of 40 was 'a very favourable auspice on your taking the lead in administration ... Believe me, a little spirit will soon restore a degree of order in my service'.$^{28}$ The King knew the morale boost to government supporters of the visible presence in the Commons of a Prime Minister determined to stand his ground, and North's gifts of Parliamentary skills and financial expertise were exactly what a Premier needed. North himself already commanded personal liking and respect in the House. And the hardline attitude he had taken on 
Wilkes and America would consolidate behind him not only the Court Party but conservative opinion generally. For former Tory squires like Sir Roger Newdigate and Sir John Glynne there was the added attraction that North was not a Whig faction leader in the mould of Fox, Grenville, Bedford, Newcastle, Rockingham or even Pitt. In that sense, too, North was the Prime Minister George III had been seeking since 1760. When accused in a Commons debate of 5 February of lacking political support, North scorned the notion of party. 'If by friends and acquaintances is meant a little knot of men who are always to be of the same opinion; in that point of view, I certainly have no friends and acquaintances. ${ }^{29}$ North was for George III the antidote to the poison of faction politics the King had been fighting all his reign.

The success of 31 January enabled North to complete his ministerial reconstruction. At the end of the year North, when seeking to recruit the followers of the then recently deceased Grenville, claimed that his intention to bring in that former Premier had met the King's disapproval, and not only because George III feared the appearance of surrender to the opposition and the displacement of many of his own 'friends'. For 'his Majesty had conceived a dislike (he Lord North could not tell why) against Mr Grenville, whom he liked less than any man, Lord Chatham excepted' ${ }^{30}$ As it was, instead of major political surgery, only minor changes were implemented. The vacancies caused by the resignations of Treasurer of the Navy Lord Howe and Irish Vice-Treasurer Lord Cornwallis, were filled respectively by Sir Gilbert Elliot and Welbore Ellis. All the three vacancies on the Admiralty Board were also filled up, one by young Charles James Fox, and most other lesser offices. The cabinet was drastically reduced in size from ten to six, for Camden, Granby, and Grafton were not replaced, and Conway was no longer willing to attend. ${ }^{31}$ Although North's uncle Lord Halifax became Lord Privy Seal, he did not enter the cabinet, which now comprised North, Southern Secretary Weymouth, Northern Secretary Rochford, American Secretary Hillsborough, Lord President Gower, and political nonentity Hawke at the Admiralty.

The opposition still aspired to bring down the ministry, but committed the tactical blunder of not forcing another major Commons debate for nearly a fortnight. Their next attack was the postponed Rockingham motion of 2 February in the Lords, where the safe administration majority meant that only prestige was at stake. The contrast in political atmosphere between the two Houses of Parliament served to emphasise Chatham's mistake in taking a peerage: would North have survived if Pitt had been in the Commons on 31 
January? Rockingham repeated Dowdeswell's motion of 25 January, and the debate continued until two hours after midnight, an almost unprecedented duration for the Lords. Although the minority was a large one for that House, 47 against 96, the debate was a triumph for administration, with Bedfordite sarcasm and invective scoring heavily against the prolixity of Chatham and the diffidence of Rockingham. Grafton spoke for the ministry, and North wrote to thank him for this act of 'friendship'. ${ }^{32}$ Administration rammed home its victory by a motion condemning any Lords resolution on a Commons decision as unconstitutional, despite Chatham's objection that the Lords had a duty to defend the people's liberties. ${ }^{33}$ The House of Lords was seldom a happy hunting ground for opposition in the later eighteenth century, and the next attack there, delayed by a Chatham illness, did not take place until 2 March, on the state of the navy. A rambling speech by Chatham was derided by Grafton as 'only the effects of a distempered mind, brooding over its own discontent', before the ministry won by 70 to $38 .^{34}$

By then the Commons battle was over. Not until 12 February did the opposition launch the next major attack there, when, in another Committee on the State of the Nation, Dowdeswell, reviving an idea he had raised in 1768 on Beckford's Bribery Bill, moved for the electoral disfranchisement of revenue officers, those thousands of voters on the government payroll. A key proposal in the Economical Reform campaign of a decade later, it was a popular topic, attracting a recorded attendance at the division of $454 \mathrm{MPs}$, the fullest House for six years. Grenvillite Harris thought it 'a rather tedious debate, full of that patriotic common-place which nobody believes that talks it, nor anyone else but a few dupes in the provinces'. ${ }^{35}$ The disbursement of what Dowdeswell calculated at $£ 600,000$ in salaries was, he said, equivalent to the bribery of electors that was forbidden by law. Cornwall MP Sir John Molesworth, whose county was full of Parliamentary boroughs and revenue officers, spoke warmly for the proposal. Administration speakers sarcastically expressed delight at having finished at last with the Middlesex Election. Colonel George Onslow, one of the former Newcastle Whigs who had stayed on in office in 1766 , sought to arouse Whig prejudices against the motion by describing Dowdeswell as 'a moderate Tory', thereby reminding MPs of the Tory or country party antecedents of the motion. Barré retorted that the objection seemed to be that it 'strikes deep at the faction who call themselves the King's Friends; those who, in their different capacities, vote for every administration'. When both Dowdeswell and 
Grenville pledged themselves to the measure if again in office, North commented that they could not think much of their own prospects. ${ }^{36}$

The motion failed by a majority of 75 votes, 263 to 188 , but there were opposition suspicions that a ministerial bench of thirty MPs was accidentally counted twice. ${ }^{37}$ Whether or not the rise in ministerial support was due to such a mistake, it delighted George III, who commented to North that 'as the question proposed by Mr Dowdeswell was well calculated to catch many persons I think it has been rejected by a very handsome majority'. ${ }^{38}$ Contemporaries were astonished that the squirearchy supported government on such a popular topic. Radical journalist John Almon appended this comment to his report. 'We are not surprised at the Court carrying the question, but a good deal so, that the country gentlemen, who have so long been exclaiming against the undue influence of the Crown, should join with them in this vote. ${ }^{39}$ Horace Walpole pointed to the revival of an ancient political tradition when he wrote that 'the old artillery of the Court, the Tories, were played against the proposal'. ${ }^{40}$ The Tory wheel had turned full circle, from 'country' back again to 'court'.

Thomas Allan, London agent of the Irish Lord-Lieutenant, reported to Dublin that 'this division, I think, adds permanency to the ministry'. ${ }^{41}$ The opposition then compounded the disaster of this defeat when Grenville, in the face of both logic and Parliamentary precedent, sought to insist on his right to divide a complex motion. The occasion was the report on 16 February of Dowdeswell's motion of 25 January as modified by North. The fiery new Speaker Sir Fletcher Norton played his part in discomforting the opposition, both then and on 19 February, when the ministry won a division on that point by 243 votes to 174 , and then confirmed North's amendment by 237 to $159 . .^{42}$ Allan deemed this 'a decent majority, besides a list of 28 who from illness or being obliged to be in the country, could not attend. I think this concludes matters for the minority for this session'. ${ }^{43}$

It did not, for the opposition believed it had not polled its full strength. 'We rather gain than lose', John Calcraft now assured Chatham, explaining the fall in the opposition vote by 'sickness, loss of relations, idleness and the Ridotto ... Had not these accidents interfered, we should have turned 200, which we have strength to do'. ${ }^{44}$ Subsequent events did not bear out this optimism. Grenville made one more attack, a motion on 28 February for the Civil List account of the year to 5 January 1770, following the presentation to the House on 12 January of the accounts from 1752 to 1769 ordered in the previous session. That was flogging a dead horse, the more so because those 
accounts showed that the deficit lacked the sinister implications of secret bribery. The ministerial majority was 262 to 165 , and Thomas Allan wrote: 'last night they [the opposition] got the coup de grâce by a majority of $97^{\prime} .{ }^{45}$ A year later North, reflecting on this Parliamentary battle to James Harris, thought the opposition had overplayed its hand, binding court and country MPs together in support of his ministry. 'That the violence of the questions kept people together, for fear of dismissal and of the expense of a general election. ${ }^{46}$

North's rise to power had been to many so unexpected that he was widely believed to be a caretaker Premier, or a figurehead for either the Bedford group or the mythical 'King's Friends'. On 2 February even Grenville told his political associates that 'Lord North was the Ostensible Minister, but no more - that the majority in the House consisted of the old Torys, of the King's Friends (as usually so called) and of the Bedford party ... that these last were the real Ministers'. ${ }^{47}$ That notion was short-lived. By early April it was common knowledge that 'there is no great harmony between the Bedfords and the Premier', who 'brought in Lord Halifax without consulting them'. ${ }^{48}$ The Bedford party, with the Duke ailing, was beginning to disintegrate, as Gower and Weymouth became intent on their own personal ambitions, while Sandwich and Rigby gravitated to North's orbit.

The myth of 'the King's Friends', as a secret ruling cabal, was, by contrast, a constant backdrop to the North ministry. James Harris wrote on 18 February, 'I hear Lord North is not so much controlled by Bloomsbury [the Duke of Bedford's residence] as by Carleton House [residence of the Princess Dowager of Wales], and the Junto there, Elliot, Morton and Jenkinson'. ${ }^{49}$ Already Thomas Townshend had declared in the House of Commons on 5 February, 'I see the administration placed in the hands of men who are ready to do most of the midnight cabinet work we have heard of ${ }^{50} \mathrm{~A}$ fuller exposition of this idea was given to the House on 2 April by Barré. Here is Thomas Allan's report of his speech:

The noble lord thinks he is minister. I tell him he is not. My friend near to me (Mr Dowdeswell) thought he was minister. He found he was not. A right honourable gentleman at the end of this bench (Mr Grenville) thought he was minister. He found he was not. I will tell them all who is minister; a junto at Carlton House, and they consist of (pointing to each as he named them) Mr Stuart Mackenzie, Sir Gilbert Elliot, Mr Jenkinson and Mr Samuel Martin. With them every point is settled and the mandate issued to your lordship. 
Almon's report has Jeremiah Dyson not Martin as the fourth member of the alleged 'cabinet of Carleton House', and recorded Dowdeswell, Grenville, and North as all denying being governed by secret influence while in office. ${ }^{51}$ There never was any such 'inner cabinet', dictating policy with North as a puppet, though such an idea long survived in the popular imagination. But the designation 'King's Friends' confusingly also had a wider connotation, that of the Court Party in Parliament, as when Barré so described such men in the debate of 12 February. This was not a new phenomenon, but its existence was highlighted in the 1760 s by the frequent changes of ministry. As Grenville said on 1 July 1770, 'those called King's men had been with him as minister, and every minister since'. ${ }^{52}$ They were not a sinister novelty of George III's reign, but a permanent feature of the political scene throughout the century.

Lord North was to be Prime Minister for 12 years. Later in 1770 his already comfortable position in Parliament was strengthened by mortality and defections among his leading opponents. Death deprived Chatham of both William Beckford, his most valuable link with the City of London, and Lord Granby, on 21 June and 18 October respectively. These events left Chatham 'without troops or generals', so Horace Walpole wrote in exaggeration. ${ }^{53}$ Shelburne, Camden and Barré still carried the flag for a party that, with Chatham himself inclined to temporary political retirement, often was known as 'the Shelburnes'. A greater blow to opposition was the death of George Grenville on 13 November, the first day of the new Parliamentary session. For this resulted in the political retirement of his brother Lord Temple $;{ }^{54}$ and in the defection to administration of much of his following. As early as 16 November North told George III that he thought there was 'an opening to acquire not only Mr Wedderburn, but all Mr Grenville's friends'. By the end of the month he had seen Lord Suffolk, whose rank gave him the best claim to be the group leader in the absence of Temple. ${ }^{55}$ The former Grenvillites negotiated individually with North, regarding the party as dissolved. Lord Hyde observed to James Harris on 11 December, 'Now Mr Grenville was dead, that his friends of principal rank looked upon themselves as disengaged, and at their liberty'.56 Suffolk was soon to become Lord Privy Seal, and Wedderburn Solicitor-General, while James Harris and Thomas Whately were also among those who took office. The faction dissolved as others, notably Lord Clive and Henry Seymour, remained in opposition. From three parties opposition was in effect reduced to barely more than one, and the Rockinghamite sense of 
isolation is conveyed in this comment by Dowdeswell to Burke on 8 February 1771. 'The Bedfords deserted us; so have the Grenvilles; and the Chathams would do the same. ${ }^{, 57}$

Despite frequent rumours, and several flirtations with administration, Chatham was never again to be in office. But his followers, though in opposition, acted as a distinctive political grouping, often disagreeing with the much larger Rockingham party on both constitutional issues, as the rights of juries in 1771 and the Royal Family Marriage Act of 1772, and imperial matters, the East India Company in 1773 and usually over America thereafter. It was a coalition of two separate factions that eventually replaced Lord North in administration in 1782, not the 'Whig party' of legend.

Lord North's establishment in power altered the character of British politics. In the 1770s this came to centre on the ministerial making of policies, and no longer, as in the 1760s, on the planning of new administrations by King and opposition alike. The end of political instability made it possible for Prime Minister Lord North, as early as the first quarter of 1770, to carry out policies for Ireland and America that both achieved short-term success. Even the imperturbable North felt the strain of conducting so much business: in a letter of 14 April to the Lord-Lieutenant of Ireland he complained of 'the whirlwind in which I have lived since the resignation of the Duke of Grafton'..$^{58}$

Ireland had been accorded priority as soon as North believed that he was safe in office. Townshend's opponents were encouraged by the news of Grafton's resignation in January 1770, but Lord North's successful establishment in power soon dashed their hopes. The new Premier was too busy ensuring his political victory to pay heed to matters of policy, Irish or American, for some weeks; but on 20 February Weymouth was able to reassure Townshend that there would be no change when the cabinet considered Ireland the next day. ${ }^{59}$ The cabinet then endorsed virtually all of Townshend's proposals concerning the Undertakers, but North would not yet commit himself to the administrative proposals. Weymouth promptly informed Townshend: the time of 'temporising' was over. ${ }^{60}$ Townshend at once sent out letters of dismissal from their offices to Lord Shannon and Speaker John Ponsonby, on 6 March. This vigorous action, he reported to Weymouth, gave the lie to opposition claims that the 'English government either would not or dared not remove a person of the Speaker's imagined consequence'. ${ }^{61}$ Shannon was also among those removed from the Irish Privy Council, but Townshend allowed 
Ponsonby to remain, since it was customary for the Speaker to be a member. Townshend, more attuned than his predecessors to public opinion, reported that there had been no hostile reaction to the fall of the Undertakers, but admitted that the prorogation of the Irish Parliament was widely unpopular. He therefore launched a press campaign, blaming it on the misbehaviour of the Undertakers and other opponents of Dublin Castle. This propaganda, he claimed, brought about a change in the public mood, assisting his efforts to recruit Parliamentary support. But he still thought it too risky to meet Parliament, and in April asked and obtained permission to wait until the next usual meeting time of October $1771 .{ }^{62}$

In Britain the attack on the Undertakers was generally approved, as Townshend's London agent Thomas Allan reported to his Chief Secretary Sir George Macartney on 29 March.

I wished to hear fully the opinion of all parties on his Excellency's transactions in Ireland, and have the satisfaction to find they are extremely approved of here. Our adherence to the same maxims, and executed with the same spirit, will ever make the residence of a Lord Lieutenant easy and agreeable. We are told Lord Shannon says he has played for a deep stake and has lost it ... As for the Speaker, he falls as much unpitied and as deservedly, as ever man did. I do believe that they had strong assurances from some here that spirited measures would not take place. ${ }^{63}$

Since the royal prerogative to appoint and dismiss office-holders was universally accepted, no open Parliamentary attack in Britain could be made on that subject. The prorogation of the Irish Parliament was quite another matter, but it was difficult for the three opposition groups to mount a concerted critique of ministerial policy. It was Grenville's ministry that had officially launched the plan of a resident viceroy, and Chatham's administration that had implemented it, with Camden widely being deemed the adviser of the prorogation. Allan reported to Macartney on 13 March that it is now said the opposition will not take any notice of what has passed in Ireland this winter' ${ }^{64}$ Allan overlooked the ministerial record, and close connections to the Undertakers, of the Rockingham party. On 3 May Lord Shannon's own brother, Rockinghamite Boyle Walsingham, moved for copies of correspondence with the Lord-Lieutenant to ascertain where the blame for the prorogation lay ${ }^{65} \mathrm{He}$ was seconded by Constantine Phipps, who neatly linked the topic to wider imperial issues by stating that no MP could doubt the right of the House to examine 
ministerial behaviour in every part of the King's dominions, a contention no minister could dispute. Phipps denounced the prorogation as 'founded upon unconstitutional principles'. Lord North promptly denied the premiss of the motion. 'There is no blame ... It was the duty of His Majesty's servants, in that situation, to advise ... that prorogation.' It signified the Crown's displeasure at the challenge to Poyning's Law. George Grenville seized the opportunity to make an indirect reference to America. 'I agree ... that it is the duty of every Minister to preserve entire the constitutional authority of Great Britain over every part of the subjects of this Empire. I wish I could say that had been done.' But the administration was behaving in Ireland as Charles II had done in England, taking money and then proroguing Parliament. Edmund Burke denied that the Irish House of Commons had broken Poyning's Law. It had simply exercised its right to reject a Bill. He and Chathamite Dunning were among speakers who attacked the impolicy and dishonesty of accepting taxes and then proroguing Parliament. What would happen next time? Throughout a long and complex debate not one speaker mentioned the dismissal of the Undertakers. The ministry triumphed at the division, by 178 votes to a mere 66 .

The main Commons debate on America had taken place two months earlier, for the ministry needed to obtain Parliamentary approval for the policy agreed upon by the Grafton cabinet on 1 May 1769, the repeal of all Charles Townshend's revenue duties except that on tea. This would be retained as both a symbol and the most lucrative source of income. The cabinet had now shed all the four members who had then favoured repeal of the tea duty also, and the decision to retain it was not an issue there, being confirmed on 2 March, only three days before the date fixed for a Commons debate on America.

North on 5 March took the line that it would be foolish to retain bad taxes, the Townshend duties on British manufactures, simply because of anger at American behaviour. The colonial trade boycott he brushed aside as ineffective, for any apparent concession under coercion would be unpopular with MPs. North then proposed repeal of all but the tea duty. Thomas Pownall moved to add that also, since it gave smugglers an advantage. These rival contentions, of course, concealed the underlying argument as to how much conciliation should be extended to America. The ensuing debate was confused. Some MPs were so undecided as to abstain from voting. The followers of Rockingham and Chatham were for complete repeal, as was 
Conway. The Grenville party would vote for no concession, and left before the end of the debate. Some administration supporters who felt the same way were spared the embarrassment of a vote on North's motion after the amendment was defeated by 204 votes to $142 .{ }^{66}$ Events turned out as the ministry hoped. 1770 saw a gradual breakdown of the colonial trade boycott, as a result of this token concession of cancelling unremunerative duties. By the end of the year the North ministry could deem the American crisis to be at an end.

Other policies pursued by Lord North in the earlier 1770s were also to enjoy success, notably his management of the national finances and his settlement of the problems of the East India Company. ${ }^{67}$ North, as a personable man, able minister, and skilful politician, fulfilled the expectations of George III. But for the War of American Independence the King might have enjoyed two decades of political tranquility before the storm of the French Revolution broke over Europe. For by 1770 the King had succeeded in his political objective, the assertion of the royal power to appoint ministers in disregard of the political connections in Parliament.

That was what George III had set out to achieve. Confusingly to more modern eyes, policy was not the King's chief criterion in selecting his ministers. Personal prejudice was the key to their choice and removal. Grenville in 1765 was aggrieved at his dismissal, for his policies had met with both success and royal approval. Antipathy towards Grenville and his colleagues was why George III replaced them by men whose political views were less congenial to the King's mind. Grenville soon came to suspect a royal veto on his return to office, but even Lord North did not know of this until he recommended Grenville for a post in 1770. By contrast, the King's correspondence with the Duke of Grafton reveals a personal affinity with a man who, for all his political defects, he would have preferred to retain as his Premier instead of appointing North in 1770 . Above all it was William Pitt whose political fortunes fluctuated in accordance with the King's view of him. Royal dislike at the beginning of his reign was soon replaced by a desire to appoint him as Premier because of his professed disapproval of party politics: but by 1770 he was the politician most detested by George III.

To reverse a cant phrase of the time, the King chose 'men not measures'. Politics were conducted by George III on a highly personal basis. Conscious of his own rectitude, he ascribed base motives to those who opposed the Crown. Hence his frequent use of the pejorative word 'factions', with the connotation of self-interested combinations acting 
against the interests of the state. In 1770 Edmund Burke produced a famous justification of party in his pamphlet Thoughts on the Cause of the Present Discontents. It was, however, one party, not a system of party politics, that Burke had in mind. For in the opinion of the Rockingham group there then existed only one party, their own, and a number of factions. One motive behind the pamphlet, as Burke observed to Rockingham on 29 October 1769, was to show how different 'the party ... as well as the persons who compose it are from the Bedfords, and Grenvilles, and other knots, who are combined for no public purpose; but only as a means of furthering with joint strength, their private and individual advantage' ${ }^{6}{ }^{68}$ By a nice irony Edmund Burke, whose political analysis of the period formed much of the basis of the historical writing that so denounced George III, here found some common ground with that King; the difference was that his monarch included the Rockingham party among the factions.

George III's conception of politics struck an old-fashioned but still popular chord. At the moment of crisis in 1770 men of both 'court' and 'country' outlook supported the Crown against the factions. Lord North that year correctly deemed it a political advantage to disparage party in theory and practice. The power of the monarchy, in the sense that George III wished to exercise it, was not yet curtailed by party politics in Parliament. Factions might be the embryos of parties, but their very multiplicity in the 1760 s afforded the King room for manoeuvre, and some active and able men, like Lord North himself, were not faction leaders at all. Still less did public opinion impact on the levers of power. In this respect the decade did witness the first signs of a more permanent development than the ephemeral phenomena, riots over food shortages and demonstrations over naval victories and defeats, sometimes prematurely described by historians as the public opinion factor in politics. The expansion of the press, and the first stirrings of political radicalism in the Wilkite movement, were portents of the future, but no more than that. By 1770 George III had made good the royal claim to appoint ministers, and for a long while yet only national disasters like the defeat in the American War would enable Parliamentary politicians to challenge that power with success.

Notes

1 Chatham Papers, III, 390.

2 Chatham Papers, III, 388-9. 
3 BL Egerton MSS. 3711, pp. 1-61 (Henry Cavendish's Parliamentary Diary). A minority list is printed in Almon, Debates, VIII, 175-7.

4 Grafton MSS. no. 541.

5 Walpole, Memoirs, IV, 23-5. Chatham Papers, III, 368-88. London Museum, 1770, pp. 120-1.

6 BL Add. MSS. 38206, fo. 195.

7 Grafton MSS. no. 541.

8 Grafton MSS. no. 544.

9 Grafton Autobiography, p. 249. One early rumour was that Yorke killed himself by cutting his arm. Macartney Papers, p. 83 .

10 Thomas, Lord North, p. 33.

11 Corr. of George III, II, 126. For these negotiations see Hamer, Thesis, pp. 153-4.

12 Grafton MSS. no. 545.

13 Grafton Autobiography, p. 249.

14 Grafton MSS. no. 546.

15 BL Egerton MSS. 3711, pp. 66-81.

16 Walpole, Memoirs, IV, 39-40. For a report of Chatham's speech, see Chatham Papers, III, 400-9.

17 Chatham Papers, III, 408-10.

18 BL Egerton MSS. 3711, pp. 106-73 (Cavendish Diary).

19 Thomas, PH, 12 (1993), 246-7.

20 Macartney Papers, p. 54.

21 Malmesbury MSS. Photocopies A759.

22 Macartney Papers, pp. 84, 93. Elliot, Border Elliots, pp. 406-7.

23 Chatham Papers, III, 412-13.

24 Elliot, Border Elliots, p. 407.

25 HMC Townshend, p. 407.

26 Walpole, Memoirs, IV, 60-1.

27 BL Egerton MSS. 3711, pp. 173-246 (Cavendish Diary). Walpole, Memoirs, IV, 50-1. Almon, Debates, VIII, 223-4. Macartney Papers, pp. 83-5.

28 Corr. of George III, II, 128.

29 Cavendish Debates, I, 439.

30 Malmesbury MSS. Photocopies A759-60.

31 Walpole, Memoirs, IV, 37-8.

32 Grafton MSS. no. 474.

33 Walpole, Memoirs, IV, 58-9. Chatham Papers, III, 415-20. Bedford Journal, p. 623. London Museum, 1770, pp. 139-45, 186-7, 190-2.

34 Chatham Papers, III, 420-3. Bedford Journal, p. 623.

35 Malmesbury Letters, I, 192.

36 Cavendish Debates, I, 442-58. Walpole, Memoirs, IV, 60. 
37 Thomas, House of Commons, pp. 279-80.

38 Corr. of George III, II, 129.

39 Almon, Debates, VIII, 231.

40 Walpole, Memoirs, IV, 60.

41 Macartney Papers, p. 88.

42 Cavendish Debates, I, 458-75.

43 Macartney Papers, p. 92.

44 PRO 30/8/25, fo. 35.

45 Cavendish Debates, I, 479-83. Macartney Papers, p. 95.

46 Malmesbury MSS. Photocopies B21-2.

47 Malmesbury MSS. Photocopies B990.

48 Macartney Papers, pp. 109, 113.

49 Malmesbury MSS. Photocopies B992. The Carlton House reference is an implication of Bute's continuing influence. The MPs named were John Morton, Charles Jenkinson and Sir Gilbert Elliot.

50 Cavendish Debates, I, 438.

51 Macartney Papers, p. 116. London Museum, 1770, pp. 271-3. This contemporary accusation against North was rather different from the one made by nineteenth-century Whig historians, namely that George III ruled himself, using North as a dummy Prime Minister.

52 Malmesbury MSS. Photocopies B996.

53 Walpole, Letters, VII, 418.

54 Malmesbury MSS. Photocopies A770-1.

55 Corr. of George III, II, 171, 174.

56 Malmesbury MSS. Photocopies A767.

57 Quoted in Escott, Thesis, p. 447.

58 Townshend Letter-Books, 7. North to Townshend, 14 Apr. 1770.

59 Townshend Letter-Books, 7. Weymouth to Townshend, 20 Feb. 1770.

60 Macartney Papers, pp. 54-7. Summary in CHOP, III, 11-12.

61 Macartney Papers, pp. 57-9. Summary in CHOP, III, 17-19.

62 CHOP, III, 14-15, 23, 27-9, 30, 31-2.

63 Macartney Papers, p. 105.

64 Macartney Papers, p. 100.

65 For this debate see the Parliamentary Diary of Henry Cavendish, BL Egerton MSS. 222, fos 64-108, from which all quotations are taken. It is partly and inaccurately printed in Cavendish Debates, I, 552-60.

66 Simmons and Thomas, Proceedings and Debates, III, 209-42.

67 Thomas, Lord North, pp. 55-8, 61-7.

68 Burke Corr., II, 101. 